\title{
アルカリ水溶液中でのクロラニル酸の電気化学特性亡 二次電池用電極活物質としての可能性
}

\author{
逢坂 哲彌*, 門間 聰之, 小茂田 訓, 白石 信浩, 菊山 亨 ${ }^{\mathrm{a}}$, 湯浅 浩次 ${ }^{\mathrm{a}}$ \\ 早稲田大学理工学部応用化学科; 各務記念材料技術研究所（テ169-8555 東京都新宿区大久保3-4-1) \\ a松下電池工業㑣（干253-8567 茅ヶ崎市本宿町11-66）

\section{Electrochemical Properties of Chloranilic Acid and its Application to the Anode Material of Alkaline Secondary Batteries}

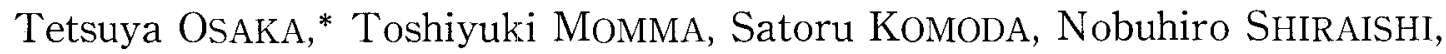 \\ Susumu KIKUYAMA, ${ }^{a}$ and Kohji YUASA ${ }^{a}$
}

\begin{abstract}
Department of Applied Chemistry, School of Science and Engineering; Kagami Memorial Laboratory for Materials Science and Technology, Waseda University (3-4-1 Okubo, Shinjuku, Tokyo, 169-8555 Japan)

${ }^{a}$ Matsushita Battery Industrial Co., Ltd. (11-66 Honjuku-cho, Chigasaki, 253-8567 Japan)
\end{abstract}

Received October 5, 1998 ; Accepted November 24, 1998

\begin{abstract}
For alkaline batteries, it is important to investigate prospective materials with higher energy density and lower cost. We paid attention to the reaction of quinone compounds and investigated the electrochemical properties of these compounds in alkaline solution and discussed the possibility for a negative active material of alkaline secondary batteries. In alkaline solution, most of these materials, e.g. $p$-benzoquinone, dissolved, while only chloranilic acid $\left(\mathrm{C}_{6} \mathrm{Cl}_{2}(\mathrm{OH})_{2} \mathrm{O}_{2}\right)$ did not. We have found that chloranilic acid is the most possible candidate for the negative active materials of alkaline batteries because of its insolubility to alkaline solutions. There were three couples of peaks in cyclic voltammogram $(-1.2 \sim-0.1 \mathrm{~V}$ vs. $\mathrm{Ag} / \mathrm{AgCl})$ for the electrode of chloranilic acid. With cathodic scan of cyclic voltammogram on $-0.8 \mathrm{~V}$ vs. $\mathrm{Ag} / \mathrm{AgCl}$, the color of solution changed. It seems that this change is caused by the influence of dissolved products, which was formed by electrochemical redox reaction of chloranilic acid around $-1.0 \mathrm{~V}$ vs. $\mathrm{Ag} / \mathrm{AgCl}$. When the charge-discharge test was conducted in the potential range between $-0.45 \mathrm{~V}$ and $-0.8 \mathrm{~V}$, no colored substance was formed in the solution and the discharge capacity reached to approximate $150 \mathrm{mAh} \mathrm{g}^{-1}$ at the first cycle. From these results, on chloranilic acid, it was suggested that there was a possibility of application for a negative active material of alkaline secondary batteries.
\end{abstract}

Key Words : Alkaline Rechargeable Battery, Quinone Compound, Chloranilic Acid

\section{1 緒 言}

携帯電子機器の小型化, 軽量化に伴いその電源となる二次 電池に関し更なる高容量化, 高性能化が求められている。こ のような中でニッケル水素電池, リチウムイオン二次電池の 2 種の二次電池が既に商品化されている。リチウムイオン二 次電池はその容量の高さから携帯機器用電源などとして大き く注目を集奴いる。一方，ニッケル水素電池などのアルカ リ水溶液系二次電池流りチウムイオ二次電池ほどの高いエ ネルギーは得られないものの大電流放電特性に優れるなどリ チウムイオン二次電池にはない特徵を有しており電気自動車 用電源などへの応用が研究されており, 今後も更なる高性能 化が求如られていくものと予想される.

アルカリ水溶液系二次電池の特性向上を考之た場合，材料 の高容量化や低コスト化が鍵であると考えられる。このため
には製造技術の向上や各構成材料の特性改善もさることなが らこれまでとは異なる全く新しい新規材料の探索も重要であ る。このため，水溶液系での新規活物質材料に関する研究も 行われている1-4). 我々はこの考え方をもとに現在用いられ ている電極材料よりも軽量, 廉価な活物質代替材料を模索し てきた。 その一例として炭素材料に着目してその水素吸蔵能 を検詂してきたが，分子軌道計算などによる結果より炭素材 料の層間への水素イオンないし原子のインターカレーション はリチウムイオンとは異なり困難である事が示唆された1).

炭素材料同様に軽量廉価でありながら水素吸蔵合金のよう にアルカリ二次電池電極活物質の可能性のある材料として有 機化合物が挙げられる．代表的な有機化合物の一種であるキ ノンはヒドロキノンと共に Fig. 1のような酸化還元系をな しており,この 2 電子反応から計算される容量は $496 \mathrm{mAh}$ ・ 
<smiles>O=C1C=CC(=O)C=C1</smiles>

Fig. 1 The redox reaction of $p$-benzoquinone.

$\mathrm{g}^{-1}$ となり高い容量が期待されるため，キノン系化合物を 種々の二次電池用活物質として用いる試みが報告されてい る $^{5-7)}$. しかしアルカリ二次電池用活物質への適用を考えた場 合 $p$ 一ベンゾキノンはアルカリ水溶液中に溶解するため水素 吸蔵合金や水酸化二ッケルの上うに固体活物質として適用す ることは困難である。本報告では数種のキノン系化合物につ いてアルカリ水溶液中での特性を検討しアルカリ二次電池活 物質としての適用の可能性について検討を試みた。

\section{1 電極活物質}

\section{2 実験方法}

キノン系化合物は Fig. 2 に示す 5 種類を取り上げた。すな わち, p-ベンゾキノン $\left(\mathrm{C}_{6} \mathrm{H}_{4} \mathrm{O}_{2}\right)$, テトラヒドロキシ-p-ベ ンゾキノン $\left(\mathrm{C}_{6}(\mathrm{OH})_{4} \mathrm{O}_{2}\right)$, テトラフルオロ-p-ベンゾキノ ン $\left(\mathrm{C}_{6} \mathrm{~F}_{4} \mathrm{O}_{2}\right)$ ，クロラニル酸 $\left(\mathrm{C}_{6} \mathrm{Cl}_{2}(\mathrm{OH})_{2} \mathrm{O}_{2}\right)$ ，キニザリン $\left(\mathrm{C}_{14} \mathrm{H}_{8} \mathrm{O}_{4}\right)$ を検討しな。電気化学特性の評洒は各キノン系化 合物粉末に導電材としてアセチレンブラック，結着材として ポリ塩化ビニルを $4: 4: 2$ の重量比で混合し, その粉末にテト ラヒドロフランを加えスラリー状にした後，集電体の発泡二 ッケル上に塗布し乾燥，プレスし電極としたものを用いて検 討した。

\section{2 特性評価}

電気化学的評価はサイクリックボルタンメトリー (CV) 及 び定電流充放電試験により行なった。また，構造解析をフー リ工変換赤外分光法 (FT-IR) 及び紫外可視分光法 (UV-Vis) により行った，電解液として $8 \mathrm{~mol} \mathrm{dm}^{-3}$ 水酸化力リウム水 溶液を用いた，測定は 3 極式セルにより行ない，参照極に $\mathrm{Ag} / \mathrm{AgCl}$ ，対極に $\mathrm{Au}$ ワイヤーを用いて行なった。サイク リックボルタンメトリーの電位走查速度は $0.1 \mathrm{mV} \mathrm{s}^{-1}$, 定電
流充放電試験における充放電電流密度はそれぞれ 50 及び 25 $\mathrm{mA} \mathrm{g}^{-1}$ とした.なお，電流值は活物質重量を基準として設定 した.

\section{3 結果及び考察}

\section{1 各キルン系化合物のアルカリ水溶液中への溶解性}

アルカリ二次電池活物質への応用を考えた場合，活物質は 現在用いられている水素吸蔵合金や水酸化二ッケル闰様に固 体である方ぶ扱い易い。このため，活物質となるキノン系化 合物はアルカリ水溶液中で固体として存在する事が望ましい と考えられる。そこで，今回検討を試みた数種のキノン系化 合物についてアルカリ水溶液への溶解性を調べた. Fig. 2 は 水酸化カリウム水溶液中に数種のキノン化合物を混入した際 の各化合物の溶解挙動をまとめたものである、多くのキノン 系化合物は水酸化力リウム水溶液中で $p$-ベンゾキノン同様 溶解が観察された，実際，それらの化合物を用いて電極を作 製し電気化学評価を試みた場合，電極を電解液に浸漬させた 際に溶液中八の活物質の溶解が観察され, 固体活物質として の使用が困難であることが示唆された，一方，クロラニル酸 は水酸化カリウム水溶液中で固体としてて存在する事が観察さ れ，これらの材料の中ではクロラニル酸に最も電極活物質と しての可能性が示唆された。

\section{2 クロラニル酸の水酸化カリウム水溶液との反応}

Fig. 3 にクロラニル酸及びクロラニル酸を水酸化カリウ 么水溶液中に添加した場合に生成される沈殿物の FT-IR 又 ペクトルを示す。雨者のスぺクトルを比較すると沈殿物にお いては 600 - $1500 \mathrm{~cm}^{-1}$ 付近のピークが消失していることか らクロラニル酸中の $\mathrm{OH}$ 基や $\mathrm{Cl}$ 基に変化が起きていること も考えられる。詳細の検討にはさらなる分析が必要であると 思われるが，いずれにせよアルカリ水溶液中でクロラニル酸 が何らかの反応を起こし沈殿を形成していることが示侁され た.

クロラニル酸がキノンの 2 電子反応をアルカリ水溶液中で 電気化学的に起こすと仮定した場合，期待される容量は 257 $\mathrm{mAh} \mathrm{g}^{-1}$ 程度であると計算される。クロラニル酸は他の多く のキノン系化合物とは異なりアルカリ水溶液中でも固体とし て存在することが明らかとなった。このため, 特にクロラニ ル酸の水酸化カリウム水溶液中での電気化学特性について検

\begin{tabular}{c|c|c|c|c|}
\hline$p$-benzoquinone & $\begin{array}{l}\text { tetrahydroxy-p- } \\
\text { benzoquinone }\end{array}$ & $\begin{array}{l}\text { tetrafluoro- } p \text { - } \\
\text { benzoquinone }\end{array}$ & chloranilic acid \\
\hline soluble & soluble & soluble & precipitate & soluble \\
\hline
\end{tabular}

Fig. 2 Quinone compounds tested by this study and their solubility in $8 \mathrm{~mol} \mathrm{dm}^{-3} \mathrm{KOH}$ solution. 

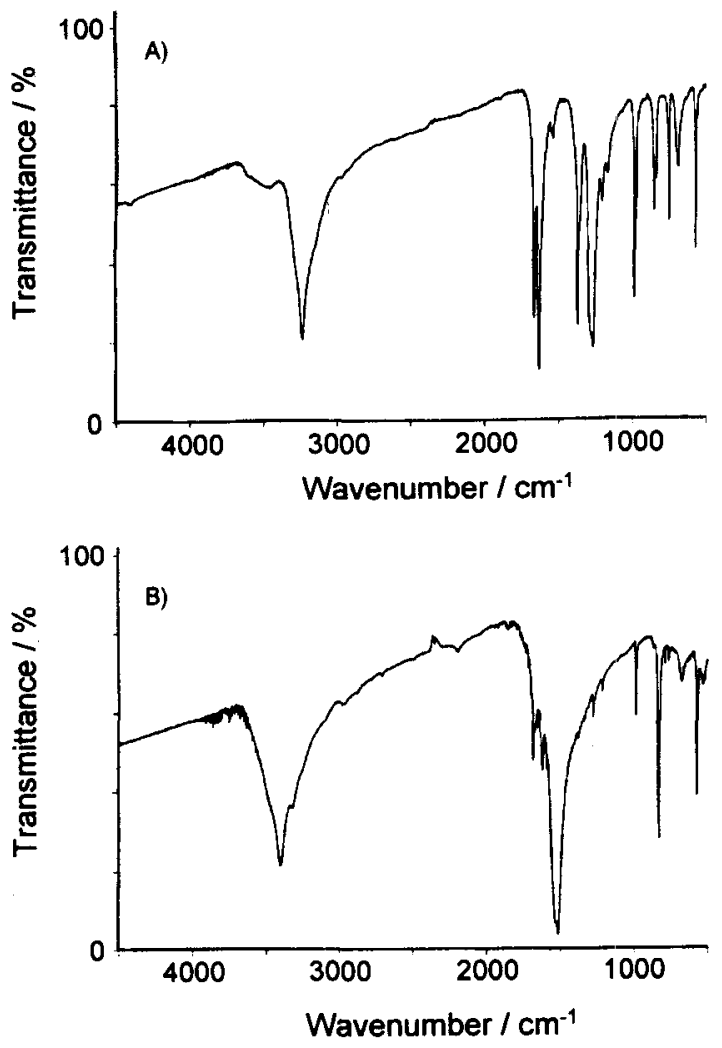

Fig. 3 FT-IR spectra of chloranilic acid; A) chloranilic acid, B) the precipitate in $\mathrm{KOH}$ solution.

討を試みた。

\section{3 クロラニル酸のアルカリ水溶液中での電気化学特性}

Fig. 4 にクロラニル酸の $8 \mathrm{~mol} \mathrm{dm}^{-3}$ 水酸化力リウム水 溶液中でのサイクリックボルタモグラムを示す. 図のように 酸化側還元側共に3つの電流ピークが確認された.さらに電 位範囲を変えた場合のボルタモグラムの変化より， $\mathrm{A}_{\mathrm{a}}$ と $\mathrm{A}_{\mathrm{c}}, \mathrm{B}_{\mathrm{a}}$ と $\mathrm{B}_{\mathrm{c}}, \mathrm{C}_{\mathrm{a}}$ と $\mathrm{C}_{\mathrm{c}}$ のピークが互いに对応していること が示唆された。このようにクロラニル酸はアルカリ水溶液中 で良好な酸化還元特性を示すことが示唆された。しかし，こ れら 3 対のピーク対のうち,ピーク対 A はサイクルと共に電 流値の減少が見られ, また, 電解液の色も無色透明から黄緑 色へと変化した．これはクロラニル酸の反応生成物が溶解性 であることに起因するものと考えられるため，還元側への電 位掃引時における溶液の変化を紫外可視吸収スペクトルによ ク観察した (Fig. 5).カソード掃引中 $-1.05 \mathrm{~V}$ vs. Ag/ $\mathrm{AgCl}$ までは電解液のスペクトルに大きな変化は見られなか ったが，それ以降までカソード掃引を行った場合 240,330 $\mathrm{nm}$ 付近のスペクトルが変化した.これらの結果から Fig. 4 中の A で示されるピークにおいて生成される還元生成物が 溶解性であることが示唆された。また，サイクルに伴いピー ク対 A が減少していくにもかかわらず他のピーク対の電流 值は減少せずむしろ増加する傾向が見られた. キノン系化合 物の電気化学的特性は種々の溶媒中で研究されているが5,8), クロラニル酸がそれらと同様に 2 電子の反応を起こすとした 場合反応は 2 または 1 段階になると考えられる。しかし，今 回の CV の結果では 3 段階のピークが得られており，それぞ

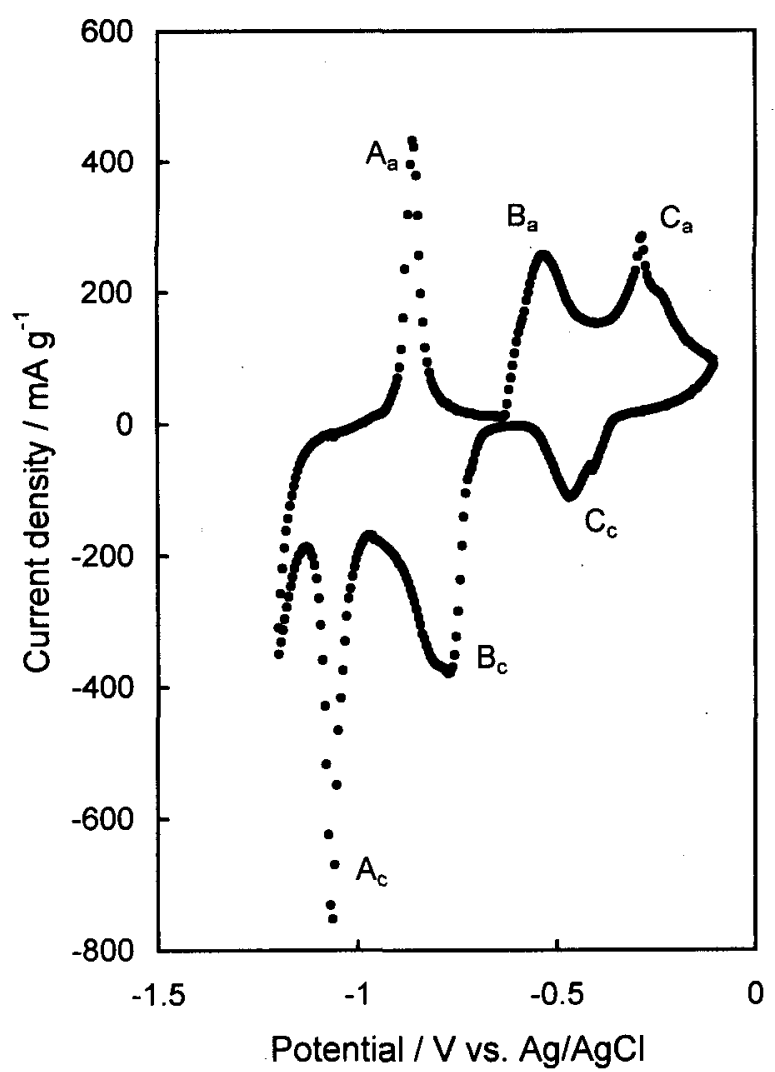

Fig. 4 Cyclic voltammogram of chloranilic acid in $8 \mathrm{~mol}$ • $\mathrm{dm}^{-3} \mathrm{KOH}$ at $0.1 \mathrm{mV} \mathrm{s}^{-1}$ at 2 nd cycle.

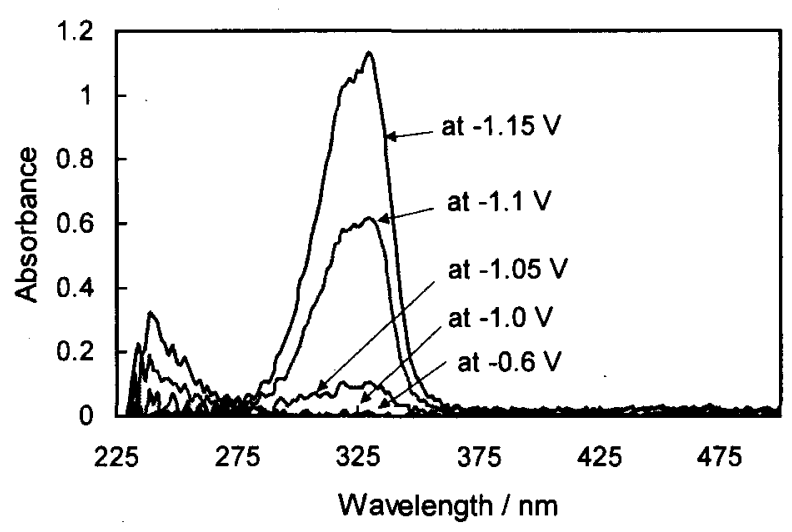

Fig. 5 Changes in absorption spectra of the electrolyte during cathodic scan at $0.1 \mathrm{mV} \mathrm{s}^{-1}$ when chloranilic acid was used as working electrode.

れの反応は独立したものであることも予想され，今後さらに 反応機構を詳細に検討していく必要があるものと思われる.

\section{4 クロラニル酸の充放電特性}

$8 \mathrm{~mol} \mathrm{dm}^{-3}$ 水酸化カリウム水溶液中での水酸化ニッケル 及び水素吸蔵合金の酸化還元電位を考虑すると, CV から推 察されるクロラニル酸の反応電位はピーク対 $\mathrm{A}$ の場合で水 素吸蔵合金とほほ同等であり，負極活物質への適用が期待さ れる.しかし，この反応における還元生成物は水酸化力リウ ム水溶液に対し溶解するためピーク対 $\mathrm{A} の$ 電位範囲に対応 


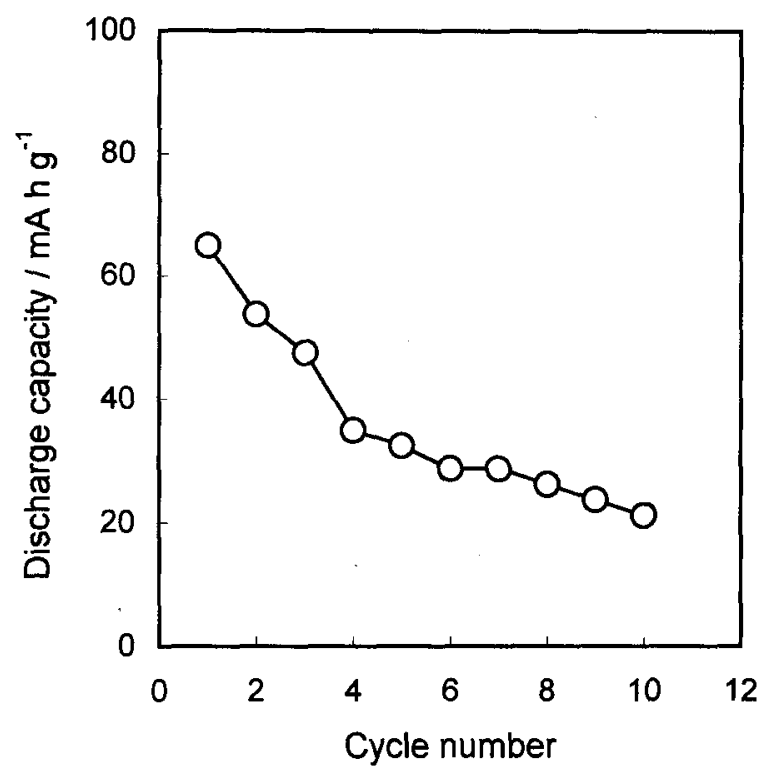

Fig. 6 Relationship between cycle number and discharge capacity of chloranilic acid in $8 \mathrm{~mol} \mathrm{dm}{ }^{-3} \mathrm{KOH}$ solution in the potential range of $-1.2 \mathrm{~V} \sim-0.8 \mathrm{~V}$ vs. $\mathrm{Ag} / \mathrm{AgCl}$.

させた充放電試験の結果ではサイクルと共に容量の少化が観 察された Fig. 6). 以上の上うに高い起電力を得るため卑な 電位で起こる酸化還元反応を充放電に利用しようと考えた場 合, 活物質の溶出反応が起こり, その結果サイクル特性が極 端に悪化するため，二次電池活物質として用いるには反応生 成物の電解液中への溶出及びそれに伴う対極への拡散を防ぐ 何らかの処置を施す必要があるものと思われる。

溶解性物質の生成するピーク対 A に対し, CV や吸光分析

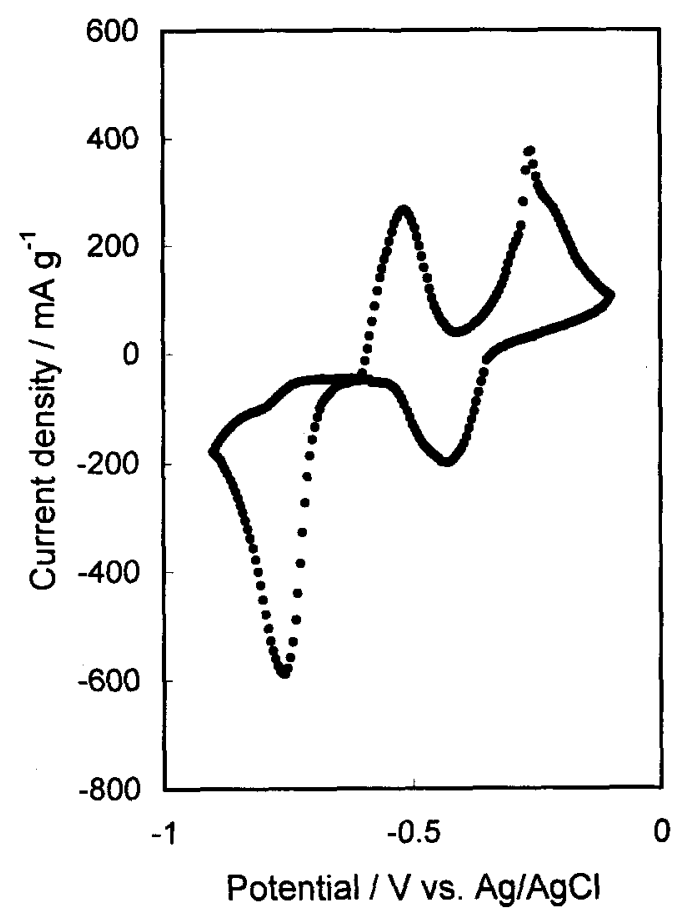

Fig. 7 Cyclic voltammogram of chloranilic acid in $8 \mathrm{~mol}$. $\mathrm{dm}^{-3} \mathrm{KOH}$ in the potential range of $-0.9 \mathrm{~V} \sim-0.1 \mathrm{~V}$ vs. $\mathrm{Ag} / \mathrm{AgCl}$ at $0.1 \mathrm{mV} \mathrm{s}^{-1}$.
の結果からピーク対 Bに関しては生成物が溶解性でない事 が示唆されているため起電力的にはピーク対 $\mathrm{A}$ に比べ劣る ものの良好なサイクル特性が期待される、CVの電位範囲を 狭め溶解の起こらないと思われる範囲で測定を試みた場合に 溶液の変色仕観察されず，また，範囲変更前と同様にピーク 対 B，Cが得られため（Fig. 7)，充放電終止電位を-0.8お よびー0.45 V vs. Ag/ $\mathrm{AgCl}$ として定電流充放電試験によ る検討を行った. Fig. 8, Fig. 9 に充放電曲線及びサイクル 特性を示す，充電時は-0.7 V, 放電時には-0.62 V 付近に プラトーの見られる曲線が得られた。 また，サイクルに伴い 徐々に放電容量は増加していく傾向が観察された。これは CVの結果とも対応しており, 酸化還元反応につ机電極内一 電解液の浸透が進行し放電容量が增加していることが予想さ れる.また，9サイクル後には $250 \mathrm{mAh} \mathrm{g}^{-1}$ の放電容量が得 られた。この容量はクロラニル酸の 2 電子反応として期待さ れる容量にほぼ等しい。このことからも CVにおける 3 段階 の反応にはキノンの 2 電子反応以外の反応が含まれることが

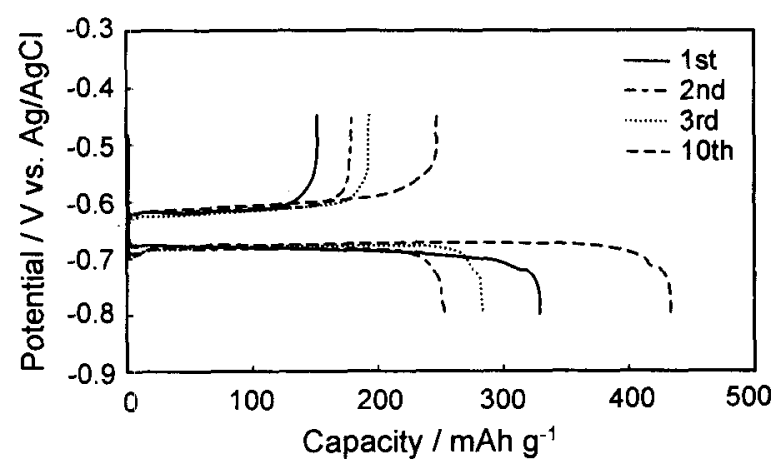

Fig. 8 Charge-discharge curves of chloranilic acid in 8 $\mathrm{mol} \mathrm{dm}{ }^{-3} \mathrm{KOH}$ in the potential range of $-0.8 \sim-0.45 \mathrm{~V}$ vs. $\mathrm{Ag} / \mathrm{AgCl}$. Charge and discharge current were 50 and $25 \mathrm{~mA} \mathrm{~g}^{-1}$, respectively.

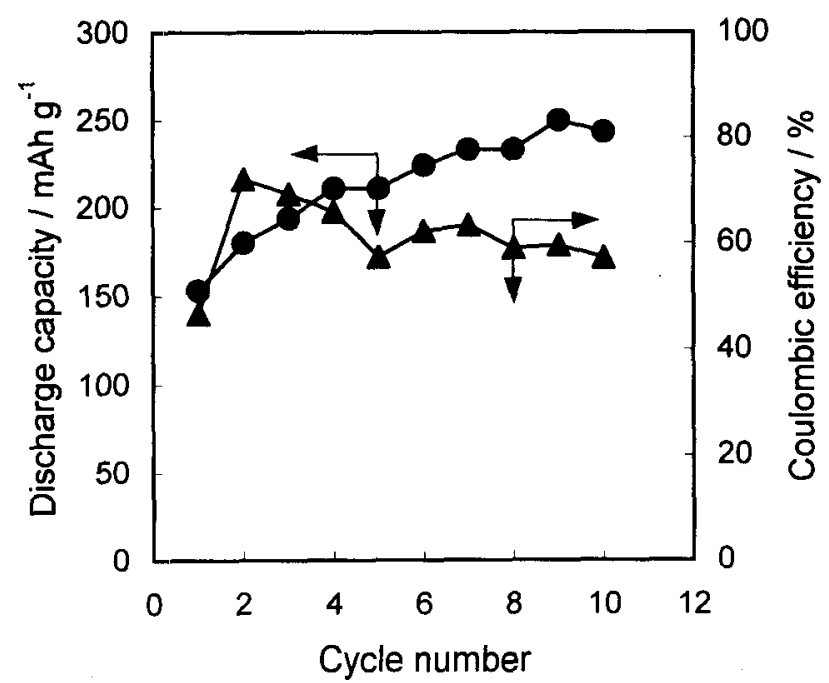

Fig. 9 Dependence of discharge capacity (O) and coulombic efficiency $(\boldsymbol{A})$ of chloranilic acid on cycle num ber in $8 \mathrm{~mol} \mathrm{dm}^{-3} \mathrm{KOH}$ in the potential range of $-0.8 \sim$ $-0.45 \mathrm{~V}$ vs. $\mathrm{Ag} / \mathrm{AgCl}$. 
推察される。

この場合のクロラニル酸電極の充放電サイクル効率は Fig. 9 に示すように $60 \%$ 程度と低い値となうた。これらの 不可逆容量の要因は充電時にクロラニル酸の還元反応以外に 電極上で水素発生などの副反応が起こっていることに起因す るものと思われる。特に初回サイクルでは充電容量が大きく， 初回サイクル特有の副反応が起こっているものと推察される が詳細は不明である。 今後は集電体や電極作製方法の変更な どによりサイクル効率の向上をはかることが課題の一つであ ると考えられる。

以上のようにクロラニル酸はアルカリ水溶液中で安定な塩 を形成し，その還元生成物は溶解性のものもあるが, 電極範 囲を適切に選択することで溶解を防ぐことが可能であること が示唆された．現在のところサイクル効率などいくつかの課 題があり, 新規アルカリ二次電池用活物質としての特性を更 に検討していく必要があると思われる。

\section{4 結 論}

キノン系化合物は酸化還元反応を起こす物質として良く知 られているが，アルカリ二次電池用活物質としての適用を考 えた場合ほとんどのキノン䒺化合物はアルカリ水溶液中に溶 解するため現在用いられているアルカリ二次電池用活物質材 料と同様に用いることは困難である。しかしクロラニル酸は 安定な塩を形成するアルカリ水溶液中に执いても固体活物質 としての適用が可能である。このクロラニル酸電極活物質 として用いた場合サイクリックボルタモグラムから 3 対の酸
化還元ピークが観察された。このうち最も㫗な電位範囲に現 れるピーク対における生成物は溶解性であることが確認され， 定電流充放電サイクルに伴い放電容量は減少していった。し かし, 電位範囲を適切に選択し, $-0.8 \sim-0.45 \mathrm{~V}$ vs. $\mathrm{Ag} /$ $\mathrm{AgCl}$ の範囲で定電流充放電を行なうことで活物質の溶解に よる容量の減少を抑制することが可能となった。このため， 反応機構の解明やサイクル効率など問題点もあるものの新規 アルカリ二次電池負極活物質としての可能性が見出された。

\section{文 献}

1) M. Watanabe, M. Tachikawa, and T. Osaka, Electrochim. Acta, 42, 2707 (1997).

2) R. Nozu and O. Matsumoto, J. Electrochem. Soc., 143, 1919 (1996).

3) W. Li, J. R. Dahn, and D. S. Wainwright, Science, 264, 1115 (1994).

4) M. Zhang and J. R. Dahn, J. Electrochem. Soc., 143, 2730 (1996).

5) J. S. Foos, S. M. Erker, and L. M. Rembetsy, $J$. Electrochem. Soc., 133, 836 (1986).

6) H. Alt, H. Binder, A. Koehling, and G. Sandstede, Electrochim. Acta, 17, 873 (1972).

7) D. P. Bhatt, M. Anbuchezian, R. Balasubramanian, R. Udhayan, and V. K. Venkatesan, J. Power Sources, 45, 177 (1993).

8) M. Oyama, T. Hoshino, and S. Okazaki, J. Electroanal. Chem., 401, 243 (1996). 